\title{
El avance de la agricultura afecta a las comunidades microbianas de suelos con
} características hidro-halomórficas

Vangeli, Sebastián ${ }^{1}$; Behrends Kraemer, Filipe ${ }^{1}$, Sydorenko, Oksana ${ }^{2}$; Correa, Olga $\mathrm{S}^{2}$; Montecchia, Marcela $\mathrm{S}^{2}$; Castiglioni, Mario ${ }^{1}$; Chagas, Celio I ${ }^{1}$

${ }^{1}$ Universidad de Buenos Aires, Facultad de Agronomía, Cátedra de Manejo y Conservación de Suelos

${ }^{2}$ INBA, UBA, CONICET, FAUBA, Cátedra de Microbiología Agrícola

*E-mail: vangeli@agro.uba.ar

Introducción: En suelos de la Pampa Ondulada bonaerense ha ocurrido una expansión de la agricultura a expensas del área ganadera, principalmente en sectores cercanos a cursos de agua con suelos de características hidro-halomórficas. Esto representa un problema complejo debido a las consecuencias productivas y ambientales que puede traer aparejadas. En trabajos anteriores, se reportaron alteraciones en las variables físicas y químicas del suelo, en la erosión, la calidad del agua de escurrimiento y la dinámica del glifosato, debidas al avance de la agricultura. Sin embargo, son escasos los trabajos que abordan los efectos del avance de la agricultura sobre las comunidades microbianas del suelo y su vinculación con las alteraciones físico-químicas producidas en el suelo. En este sentido, existen variables edáficas relativamente estables (e.g. granulometría, pH) o dinámicas (e.g. materia orgánica, estabilidad estructural), las cuales pueden influenciar a las comunidades microbianas presentes. Este trabajo tuvo como objetivo evaluar el efecto del avance de la agricultura sobre las comunidades microbianas en suelos del plano aluvial del Arroyo del Tala,y su relación con variables edáficas que sufren o no modificaciones debido a este cambio en el uso de la tierra.

Materiales y métodos: Se trabajó sobre un complejo de suelos, compuesto por Natracuoles, y en menor medida, por Natracualfes y Argiudoles típicos de la cuenca del Tala (Prov. Bs. As.). Se realizaron dos muestreos (diciembre 2014 y mayo 2015). Los tratamientos fueron: 1) "agrícola": agricultura extensiva en suelos con características hidro-halomórficas subsuperficiales 2) "ganadero": cría bovina de baja carga sobre vegetación de pastizal natural, sobre suelos similares a los agrícolas 3) "ganadero sódico": similar al caso anterior, pero sobre suelos con características hidro-halomórficas desde la superficie. La caracterización de la estructura genética de la población bacteriana se realizó mediante el análisis por DGGE de los genes ribosomales $16 \mathrm{~S}$ (16S rADN) amplificados por PCR a partir del ADN total de suelo.Posteriormente, a partir de los perfiles de bandas obtenidos, se calcularon índices de biodiversidad: riqueza (S, número de bandas), diversidad de Simpson (D), dominancia (1-D) y equitatividad. Las diferencias en la estructura bacteriana entre tratamientos se evaluó mediante ANOSIM ( $\mathrm{n}=9999$ ). Los perfiles cuantitativos (presencia e intensidad de bandas) se representaron gráficamente en un escalamiento multidimensional no métrico (NMDS), que incluyó las variables edáficas profundidad al horizonte argílico (Bt), pH, carbono orgánico total (COT), estabilidad estructural (EE), hidrofocidad (Hdf) y densidad aparente (DAP).

Resultados: A partir del análisis de la estructura de la comunidad bacteriana se logró discriminar entre los suelos agrícolas y ambos ganaderos $(\mathrm{P}<0,02)$, mientras que estos últimos presentaron diferencias de menor magnitud. El suelo agrícola presentó una mayor dominancia y menor riqueza y diversidad bacteriana respecto a los suelos ganaderos $(\mathrm{P}<0,01)$. No se encontraron diferencias en equitatividad $(\mathrm{P}>0,05)$. El NMDS mostró un agrupamiento de los sitios según su uso (Figura 1), de manera similar para ambas fechas. El eje 1, caracterizado por la profundidad al horizonte Bt y el pH (variables estables), separó los suelos agrícolas y ganaderos de losganadero sódicos. Eleje 2, caracterizado por el COT y la EE (variables dinámicas) discriminóentre el uso ganadero (>MO y EE) y el agrícola.

Conclusiones: El avance de la agricultura alteró la estructura y diversidad de las comunidades bacterianasen suelos hidrohalomórficos de la Pampa Ondulada. Las comunidades bacterianas presentes fueron influenciadas por variables edáficas dinámicas, las cualesresultaron modificadas por el cambio de uso de la tierra (EE, COT) y también por parámetros edáficos más estables $(\mathrm{pH}, \mathrm{Bt})$. Cuando se pretende caracterizar el efecto del cambio en el uso de la tierra sobre las comunidades microbianas del suelo, deben considerarse también los parámetros edáficos, tanto los estables como los variables, a fin de lograr una mejor interpretación de los resultados.

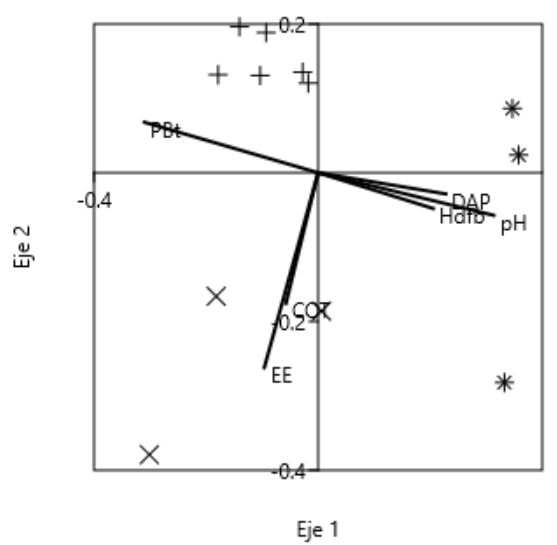

Figura 1:Escalamiento multidimensional no métrico (NMDS) empleando distancias de Bray-Curtis a partir de los perfiles genéticos bacterianos de DGGE (16S rADN) para el muestreo mayo 2015. Referencias: + Agrícola; X Ganadero; * Ganadero Sódico. Estrés = 0,1464. 